exert their influence only after implantation, we none the less envisage the possibility of the flat-mount technique, when further perfected particularly in its quantitative aspects, becoming a valuable adjunct to other drugtesting and screening procedures, both generally and in relation to pregnancy.

We are indebted to Dr. G. F. Somers (The Distillers Co. Ltd.) for gifts of thalidomide and phthaloyl-DL-isoglutamine.
REFERENCES

Adams, C. E., Hay, M. F., and Lutwak-Mann, C. (1961). J. Embryol. exp. Morph." 9, 468

Lutwak-Mann, C. (1954). Ibid., 2, 1.

(1962) Nature (Lond.), 193, 653.

Boursnell, J. C., and Bennett, J. P. (1960). J. Reprod. Fertil., 169.

Hay, M. F., and Adams, C. E. (1962). J. Endocr., 24, 185 .

Moog, F., and Lutwak-Mann, C. (1958). J. Embryol. exp. Morph., 6, 57.

\title{
BLOOD GROUPS AND DISEASE
}

\section{ABH ANTIGENS ON hUMAN DUODENAL CELLS}

BY

\section{W. K. COWAN, M.D., M.R.C.P.Ed.}

\section{Clatterbridge General Hospital, Bebington, Cheshire, and Department of Medicine, University of Liverpool}

\section{[With Special Plate]}

Although the relationship between blood group $O$ and duodenal ulcer was first pointed out by Aird et al. (1954), its significance remains completely unknown. However, in the years since the original publication further work has both amply confirmed the association and has examined various hypotheses put forward to explain it. The theory of racial stratification which supposes that there may be a stratum of society, such as the Scots, where the incidence of both blood group $\mathrm{O}$ and duodenal ulcer is relatively high is still under investigation (Clarke, 1961), but racial stratification becomes less and less a possibility as further work continuing to show an association between blood group $\mathbf{O}$ and duodenal ulcer is reported from centres all over the world, embracing populations with different blood-group distributions.

Two hypotheses to explain peptic ulcerogenesis followed the finding of the firm relationship between duodenal ulceration and non-secretion (Clarke et al., 1956). First, it seemed that the blood-group antigens present in the subject's secretions might be able in some chemical or even physical way to protect the duodenal mucosa from ulceration. Such evidence as there is argues against such a suggestion (Clarke et al., 1959 ; McConnell, 1959 : Doll et al., 1961), yet it still remains a possibility. Second, the blood-group substances might be protective in an immunological way.

An immunological hypothesis has in fact been put forward by Cain (1957). He suggested that blood-group agglutinins found in leguminous plants (lectins) and swallowed in food might be ulcerogenic. In secretors this damaging effect would be neutralized by the bloodgroup antigens in the saliva and gastric juice. The hypothesis has lost some of its force following the work of Lawler (1957), who showed that many of these plant agglutinins are inactivated by heating: but the theory remains an attractive one. If indeed these agglutinins possess ulcerogenic properties, then the effect would probably be influenced by whether or not there were antigen sites on the mucosal surface cells with which they could combine or react. It therefore seemed worth while to investigate whether duodenal cells did in fact possess antigen sites, and, if so, whether there was any difference between the amount of blood-group substances as between secretors and non-secretors.
The blood-group antigen distribution in human duodenal mucosa has been investigated by Glynn et al. (1957), who used rabbit antisera and the fluorescent antibody technique. In the duodenum of group A and B secretor subjects, group antigen was found mainly in the goblet cells of the superficial epithelium, the columnar cells staining only faintly. A thin line of fluorescence outlined the lumina of the crypts indicating goblet-cell secretions coating the whole epithelial surface, and Brunner's glands were stained brightly. This situation contrasted with that in non-secretor subjects where no staining of the villi or crypts could be seen but where Brunner's glands nevertheless stained as brightly as in secretor subjects. The presence of $\mathbf{H}$ substance was not so predictable, since it was occasionally absent in the superficial mucosal zone in either secretor or non-secretor patients of either group $\mathbf{O}$ or A.

Szulman (1960) used conjugated human immune antisera to investigate the distribution of $A$ and $B$ antigens, and his findings in the duodenum confirm those of Glynn and his colleagues; he also noted antigen-loaded mucus welling up to the surface from Brunner's glands even in non-secretors. Selsnick (1959) examined human duodenal cells by both the fluorescent antibndy and the mixed-cell agglutination techniques and failed consistently to find blood-group antigen in the duodenal mucosal cells of non-secretor subjects by either method. Thus the consensus of evidence is that $\mathrm{ABH}$ antigens are not demonstrable on human duodenal cells of nonsecretor subjects. The present study was undertaken to confirm Selsnick's findings using mixed-cell agglutination, a more sensitive technique than the fluorescent antibody method. Nearly four times as many patients have been studied by this method. and the controls have been different from those in Selsnick's project.

\section{Material and Methods}

Specimens of fresh human duodenum were secured at gastrectomy, and in each instance a paraffin block of the tissue confirmed that it was in fact duodenum. Suspensions of duodenal mucosal cells, obtained by agitating pieces of mucosa in a solution of oxidized ascorbic acid (Cowan, 1962), were stored in $20 \%$ glycerol in normal saline at $-20^{\circ} \mathrm{C}$. 
Mixed-ce!l agglutination was performed after the manner of Coombs et al. (1956), the following tubes being set up for group A and B tissues:

\section{Tissue}

Duodenal cell group A

Duodenal cell group A

Duodenal cell group $\mathbf{O}$

Antiserum Red cell

$\therefore$ Anti A $\ldots$ A $\ldots$

$\therefore$ Ant A $\ldots$ O $\ldots$ Control

With group $O$ tissues, two tubes were set up, and Ulex extract was used as a source of anti $\mathrm{H}$ :

\section{Tissue}

Duodenal cell group 0

Antiserum Red cell

Duodenal cell group 0

$\begin{array}{llllll}\text { Ulex } & \ldots & \mathbf{O} & \cdots & \text { Test } \\ & \text { Anti } & & & & \end{array}$

It was found that for satisfactory mixed-cell agglutination it was necessary to incubate the tissue cells and antibody at room temperature for two hours or more. High-titre immune antiserum is also advisable. The results were viewed under a phase-contrast microscope.

A specimen of saliva was obtained from all patients and the secretor status determined by the method of antibody inhibition (Race and Sanger, 1958). In 49 patients the gastric juice was also examined (when titration with a buffer was necessary to avoid red-cell lysis), and in this series there was complete concordance between the gastıic juice and salivary findings. The buccal epithelial cells of some of the patients were also examined by mixed-cell agglutination as a control of technique. as Swinburne et al. (1961) have shown that $A$ and $B$ antigen sites can be demonstrated on the buccal cells even of non-secretors.

\section{Results}

Duodenal specimens were examined from 87 patients, 62 of whom also had their buccal cells tested. The results are represented in Tables I, II, and III, and the photographs (Snecial Plate. Figs. 1-4) give examples of positive and negative findings.

Table I.-Blood Group A Parients: 28 Duodenal Specimens, 20 Buccal Cell Specimens

\begin{tabular}{|c|c|c|c|c|}
\hline \multirow{2}{*}{$\begin{array}{c}\text { Mixed- } \\
\text { cell } \\
\text { Agglutination }\end{array}$} & \multicolumn{2}{|c|}{ Secretors } & \multicolumn{2}{|c|}{ Non-secretors } \\
\hline & Dundenum & Buccal Cells & Duodenum & Buccal Cells \\
\hline $\begin{array}{l}\text { Positive ... } \\
\text { Negative .. }\end{array}$ & $\begin{array}{r}18 \\
2\end{array}$ & $\begin{array}{r}14 \\
0\end{array}$ & $\begin{array}{l}4 \\
4\end{array}$ & $\begin{array}{l}5 \\
1\end{array}$ \\
\hline
\end{tabular}

TABle II.-Blood Groups $B$ and $A B$ Patients: 10 Duodenal Specimens, 9 Buccal Cell Specimens

\begin{tabular}{|c|c|c|c|c|}
\hline \multirow{2}{*}{$\begin{array}{c}\text { Mixed- } \\
\text { cell } \\
\text { Agglutination }\end{array}$} & \multicolumn{2}{|c|}{ Secretors } & \multicolumn{2}{|c|}{ Non-secretors } \\
\hline & Duodenum & Buccal Cells & Dundenum & Buccal Cells \\
\hline $\begin{array}{l}\text { Positive } \\
\text { Negative }\end{array}$ & $\begin{array}{l}8 \\
0\end{array}$ & $\begin{array}{l}6 \\
0\end{array}$ & $\begin{array}{l}0 \\
4\end{array}$ & $\begin{array}{l}2 \\
1\end{array}$ \\
\hline
\end{tabular}

Table IIl.-Group O Patients: 47 Dundenal Specimens, 33 Buccal Cell Specimens

\begin{tabular}{|c|c|c|c|c|}
\hline \multirow{2}{*}{$\begin{array}{c}\text { Mixed- } \\
\text { cell } \\
\text { Agglutinations }\end{array}$} & \multicolumn{2}{|c|}{ Secretors } & \multicolumn{2}{|c|}{ Non-secretors } \\
\hline & Dundenum & Buccal Cells & Duodenum & Buccal Cells \\
\hline $\begin{array}{lll}\text { Positive } & \ldots & \ldots \\
\text { Negative } & . & \ldots\end{array}$ & $\begin{array}{r}33 \\
0\end{array}$ & $\begin{array}{r}20 \\
0\end{array}$ & $\begin{array}{l}6 \\
8\end{array}$ & $\begin{array}{l}4 \\
9\end{array}$ \\
\hline
\end{tabular}

Since the great majority of the specimens were received from patients suffering from duodenal ulceration. the numbers do not allow a comparison of results obtained from duodenal ulcer patients and patients without ulcers.

\section{Discussion}

The results of the present study are unequivocal regarding the presence of $\mathrm{ABH}$ antigens on the duodenal cells of secretors of all groups, since with very few exceptions $A$ and $B$ antigens have been shown on the cells of $A$ and $B$ subjects, while $H$ substance has been shown, by Ulex extract, to be present on the cells of group $O$ patients.

The position in the cases of the non-secretors is not as clear-cut. In the group $\mathbf{O}$ subjects it is of interest that $H$ substance could often not be demonstrated on the buccal cells although in a greater proportion of the corresponding duodenal cells it could be identified. The figures for all group $\mathbf{O}$ patients should, however, be considered apart from those obtained in groups $\mathrm{A}$ and B subjects, since it would be imprudent to compare results given by a plant agglutinin with those where an agglutinin of animal origin had been used. Further, the results from group A subjects have been separated from the rest, since it was with this group that hightitre immune antiserum was employed-a measure leading to more satisfactory mixed-cell agglutination. In considering the non-secretor patients of groups other than $\mathrm{O}$, and in particular those of group $\mathrm{A}$, it can be noted first that the results of the buccal-cell study are consistent with those of Swinburne et al. (1961). These workers showed that, using human immune anti- $\mathbf{A}$, positive mixed-cell agglutination could be obtained on the buccal cells of secretor subjects and non-secretor group $A_{1}$ subjects ; negative agglutination occurred only with non-secretor group $A_{2}$ individuals.

If, therefore, the buccal-cell study is regarded as a control of technique, the results obtained with the nonsecretor duodenal cells indicate that, using this method, group antigens can be demonstrated in about half the specimens examined. An alternative explanation would be that in non-secretor epithelial cells the antigen is so scanty that it cannot be shown by fluorescent antibody methods, and indeed is only demonstrable in a proportion of subjects using mixed-cell agglutination. It is possible to suppose that in non-secretor individuals who possess, it is agreed. group substance in Brunner's glands (see Szulman, 1960), enough of this secretion is absorbed on to the duodenal mucosal cells to permit positive mixed-cell agglutination in a proportion of instances. That this is not evident with fluorescent antibody techniques may be due to the method being rather less sensitive ; this is illustrated by the survey of Holborow et al. (1960), where group antigen could be detected in the thyroid by mixed-cell agglutination but not by the fluorescent antibody technique.

The work therefore demonstrates, using mixed-cell agglutination technique, an antigenic difference between the duodenal cells of secretor and non-secretor subjects ; the findings are consistent with those of Glynn et al. (1957) and Szulman (1960), but less unequivocal than those of Selsnick (1959).

If the duodenal mucosal cells of non-secretors possessed no blood-group antigen sites, Cain's immunological theory of ulcerogenesis would be less cogent, since the hypothetical ulcerogens would not be fixed or neutralized on the mucosa. The present work therefore offers slightly more support for the theory than previous studies, and in demonstrating a quantitative antigenic difference between duodenal and buccal cells of nonsecretor subjects it may throw some light on the physiology of the duodenum. Until this is understood, and in particular what physiological role is played by blood-group substances in upper alimentary secretions, the significance of the factors which determine duodenal ulceration cannot be precisely evaluated. 


\section{Summary}

Human duodenal mucosal cells have been examined by mixed-cell agglutination for the presence of bloodgroup antigens.

The secretor status of the patients has been determined, and in a proportion of cases gastric juice as well as saliva has been studied. Mixed-cell agglutination has also been performed on the buccal cells from a percentage of subjects as a control of technique.

The results indicate that antigen is present in secretor subjects, but is absent or very scanty in at least a proportion of non-secretor individuals.

The possible relevance of this finding to the problem of duodenal ulcerogenesis is examined.

This work formed part of a project the results of which were submitted as a thesis for the degree of M.D. of the University of Liverpool. I am grateful to Dr. R. R. A. Coombs, Dr. C. A. Clarke, and Dr. R. B. McConnell for their help and suggestions, and to Mr. W. T. A. Donohoe, who carried out the serological testing of the saliva and gastric-juice specimens.

\section{REFERENCES}

Aird, I., Bentall, H. H., Mehigen, J. A., and Roberts, J. A. F. (1954). Brit. med. J., 2, 315

Cain, A. J. (1957). Lancet, 1, 212

Clarke, C. A. (1961). Progress in Medical Genetics, Chapter 4. Grune and Stratton, London.

Edwards, J. W., Haddock, D. R. W., Howel-Evans, A. W. McConnell, R. B., and Sheppard, P."M. (1956). Brit. med. J., 2, 725

Evans, D. A. P. McConnell, R. B., and Sheppard, P. M (1959) Ibid., 1, 603

Coombs, R. R. A., Bedford, D., and Rouillard, L. M. (1956) Lancet, 1, 461 .

Cowan, W. K. (1962) J. Path. Bact In press.

Doll, R., Drane, H., and Newell, A. C. (1961). Gut, 2, 352

Glynn, L. E., Holborow, E. J., and Johnson, G. D. (1957) Lancet, 2. 1083.

Holborow, E. J., Brown, P. C., Glynn, L. E., Hawes, M. D., Gresham, G. A., O'Brien, T. F. and Coombs, R. R, A (1960). Brii. J.exp. Path., 41, 430

Lawle,, S. (1957). Demonstration at Genetical Society Meeting, John Innes Horticultural Institution.

McConnell, R. B. (1459). Gastroenterologia (Basel), 92, 103.

Race, R. R., and Sanger, R. (1958). Blood Groups in Man. Blackwell, Oxford.

Selsnick, F. (1959). Ch.M. thesis, University of Liverpool.

Swinburne, L. M., Frank, B., and Coombs, R. R. A. (1961). Vox Sang (Basel), 6, 274

Szulman, A. E. (1960). J. exp. Med., 111, 785.

\section{INFLUENCE OF THE SECRETOR AND LEWIS GENES ON SUSCEPTIBILITY TO DUODENAL ULCER}

\section{P. A. J. BALL, M.D., M.R.C.P. \\ West African Medical Research Fellow, Department of Medicine, University College Hospital, Ibadan, Nigeria}

In all series so far published it has been found that people of blood group $\mathrm{O}$ and non-secretors of the ABO blood-group substances suffer from duodenal ulcer more often than the rest of the population (Doll et al., 1961). This paper describes an attempt to define the way in which non-secretion affects susceptibility to duodenal ulcer.

The secretor gene has no known direct expression, but exerts its effects on the composition of the mucous secretions of the body by interaction with the $A B O$ and Lewis genes, all three genes being inherited independently of each other. The saliva of all secretors contains $H$ antigen, and that of blood group $A, B$, and $A B$ secretors A, B, or both; the saliva of non-secretors lacks ABO specificity. The relationship between the secretor and Lewis genes is less well understood. The simplest explanation of the known facts is that possession of the Lewis gene, which confers the ability to synthesize Le $^{\text {a }}$ substance, a mucopolysaccharide closely related to the ABO blood-group substances, is inherited as a dominant character. The saliva of people who are genetically capable of synthesizing Le $\mathrm{e}^{\mathrm{a}}$ substance usually contains very much more of the substance if they are $\mathrm{ABO}$ non-secretors (with the red-cell phenotype $\operatorname{Le}(a+b-))$ than if they are secretors (red-cell phenotype $\operatorname{Le}(a-b+))$, perhaps because in secretors the $\mathrm{ABO}$ gene has priority in determining the chemical nature of a limited available quantity of water-soluble mucopolysaccharide (Race and Sanger, 1959). Persons who are genetically incapable of synthesizing $\mathrm{Le}^{\mathrm{a}}$ substance all have the red cell phenotype $\operatorname{Le}(a-b-)$, and secrete at most traces of the substance in their saliva or other mucous secretions.

It follows that there are at least three possible causes for an excess of non-secretors among patients with duodenal ulcer. (1) The absence of $\mathrm{ABO}$ specificity in mucus is disadvantageous by comparison with its presence. (2) Some other as yet unknown expression of the secretor gene influences susceptibility to ulceration. (3) Both the Lewis and secretor genes are involved. An excess of non-secretors would result if $\operatorname{Le}(a+b-)$ persons were more susceptible to duodenal ulcer than $\operatorname{Le}(a-b+)$ or $\operatorname{Le}(a-b-)$ persons.

In the first two cases the Lewis gene system will not be involved, and the relative numbers of subjects with and without the Lewis gene will be the same among patients with duodenal ulcer as in the general population. In the third case any excess of non-secretors should be made up entirely of $\operatorname{Le}(a+b-)$ subjects, and there should be both relatively and absolutely fewer non-secretors who are $\operatorname{Le}(\mathrm{a}-\mathrm{b}-)$ among patients with duodenal ulcer than among healthy people.

It should be possible to distinguish between these alternatives by comparing the frequencies of the different Lewis phenotypes in subjects with and without duodenal ulcer. This cannot easily be done in Europe, where only about $6 \%$ of the population is $\operatorname{Le}(a-b-)$. Some $35 \%$ of West Africans are Le $(a-b-)$, however, and this paper describes such a comparison between Nigerians belonging to a single tribe.

\section{Material}

The ABO group, secretor status, and Lewis phenotype have been determined in 172 male patients of the Yoruba tribe with duodenal ulcer. They all gave a suggestive history and had radiological evidence of chronic ulceration, and the diagnosis was confirmed at operation in 106 of them. In addition, the $\mathrm{ABO}$ group was known in 218 of a further 229 Yoruba patients of both sexes who were operated upon for duodenal ulcer in this hospital between 1957 and 1960. 


\section{W. K. COWAN: BLOOD GROUPS AND DISEASE}
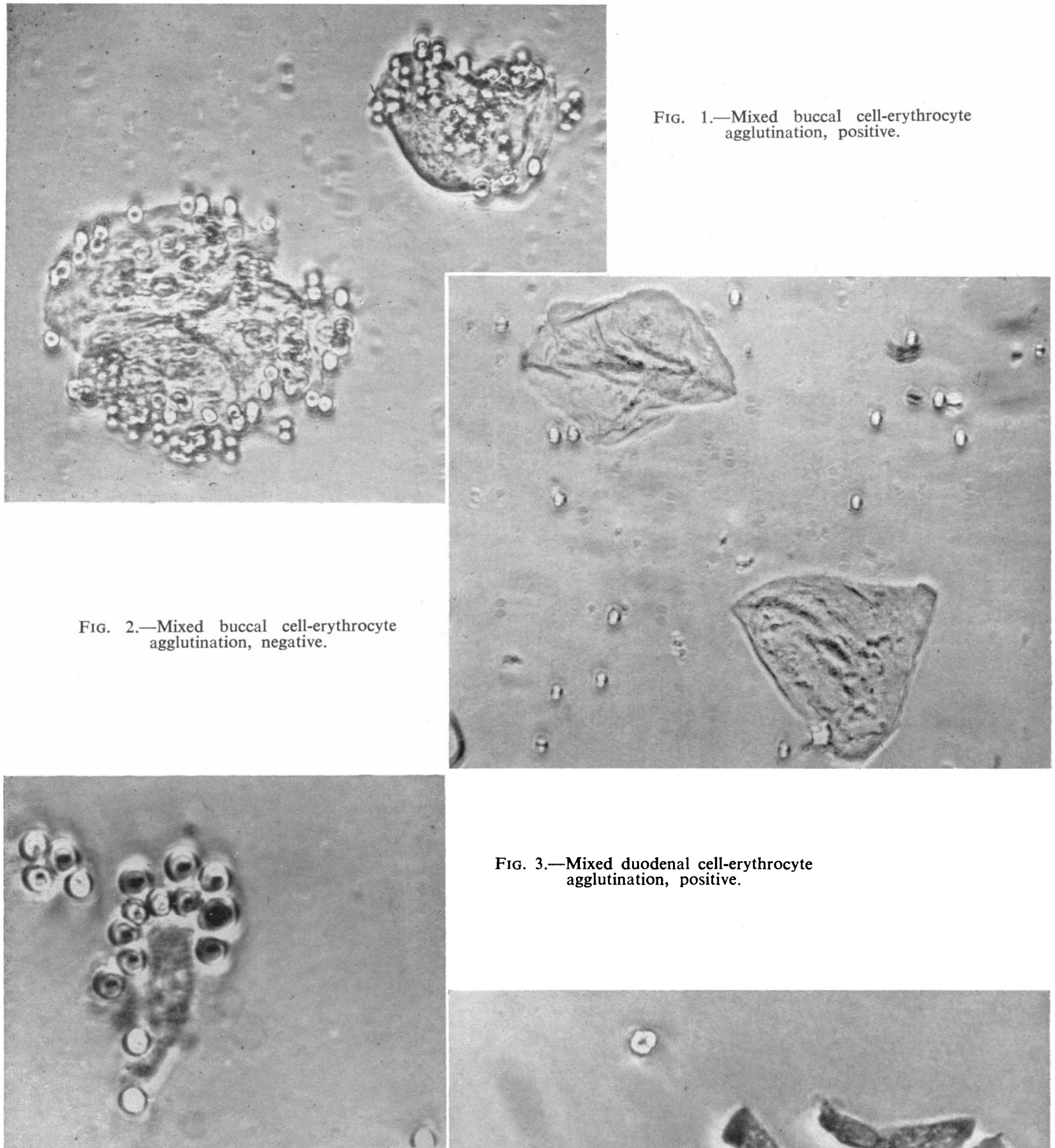

Fig. 3.-Mixed duodenal cell-erythrocyte agglutination, positive.

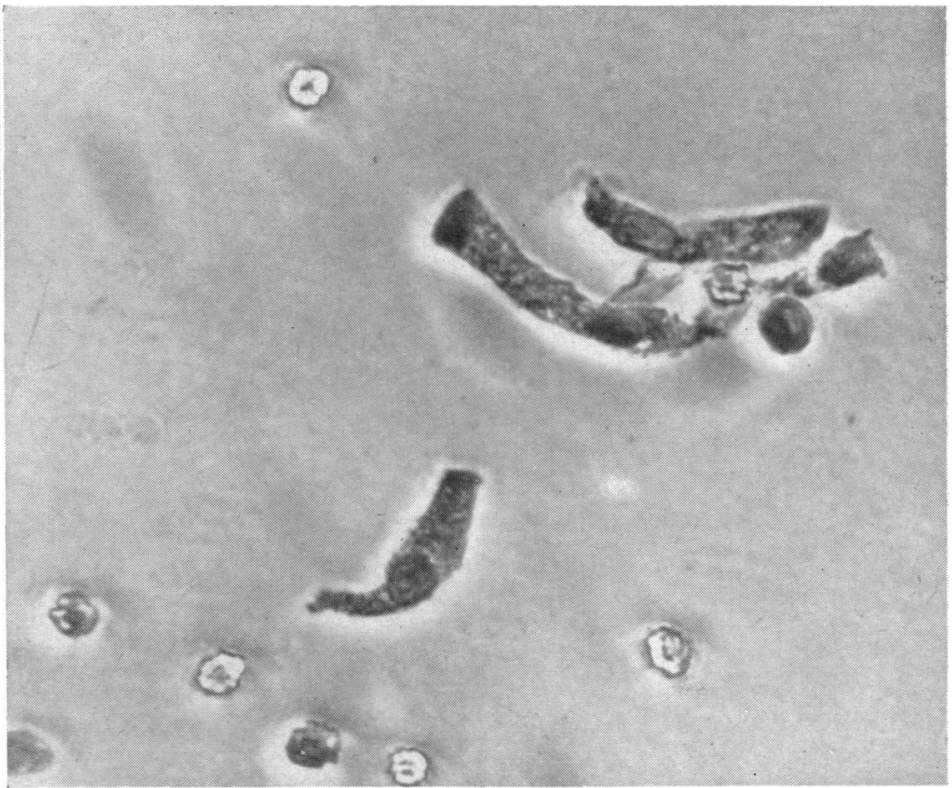

